\title{
Mathematical model of analytical approach of comparative analysis of productivity of agricultural machinery when using visualization technology
}

\author{
D. A. Mashtakov*, $Y$. $V$. Larina, and $E . V$. Golysh
}

Saratov State Agrarian University named after N.I. Vavilov, 410012, 1, Teatralnaya sq., Saratov, Russian Federation

\begin{abstract}
Establishment of the effectiveness of organic micronutrient complex on growth and biological mass of juniper juniper (Juniperus sabina L.) seedlings in an enclosed ground UNPK "Agrocenter" was the purpose of the study. The application of organic micronutrient complex increased the current growth of juniper seedlings, root neck diameter, root system length and total height of planting material of juniper. Close interdependence between the growth of juniper seedlings and the dose of fertilizer used is determined by coefficients of determination equal to 0.95 0.98 . Accumulation of the biological mass of seedlings, depending on the applied dose, occurs with an increase in the participation of roots and needles by 1.79 and 1.1 times, respectively, in the total biomass of seedlings.
\end{abstract}

\section{Introduction}

Containerized planting material has been gaining popularity in recent years due to its almost $100 \%$ rooting ability during planting operations, increased planting time and high quality planting material [1].

Cossack juniper (Juniperus sabina L.) is widely used in landscaping of the Volga region due to its high frost resistance, fast growth and high ornamental value [2-4]. Cultivation of Cossack Juniperus in containers allows to obtain high-quality planting material, with practically guaranteed $100 \%$ survival rate [5]. In container cultivation of juniper there is a certain spatial restriction of plant root system, so special attention is paid to timely replenishment of nutrients lost from container substrate. This is pointed out by many domestic and foreign researchers: Kupriyanova A.G. [6], Lyubimov V.B. [7], Kabanina S.V. [8], Whitcomb C.E. [9].

The use of growth preparations can reduce the time of growing planting material to a standard size, increase the above-ground and root biomass and biometric indicators of plants, which favorably affects the growth of plants after transplanting to the object of landscaping.

\footnotetext{
${ }^{*}$ Corresponding author: 1msus1920@mail.ru
} 
The aim of the study is to determine the effectiveness of organic micronutrient complex (OMEC) on growth and biometric indicators of Cossack juniper during container cultivation in UNPK "Agrocenter".

\section{Methods}

Studies on the growth of Cossack juniper seedlings were carried out in Saratov "Agrocenter" UNPK in an enclosed ground. The volume of containers was 2.51 . Optimal microclimatic conditions were regulated by a fogging unit. The temperature regime during the experiment was 23- $28{ }^{\circ} \mathrm{C}$. Experiments were set up by the method of randomized replications in 3 -fold repetition by cuttings method [10].

Material for cuttings was taken from mother plants on the territory of UNPK "Agrocenter". The length of cuttings was $25 \mathrm{~cm}$. After the beginning of shoots regrowth and formation of roots in cuttings, planting material was transplanted into containers. Used substrate for growing was a mixture of sand and peat in a ratio of 1:1. As a growth preparation dry organic micronutrient complex "Universal" with a complex of trace elements in the form of L-asparaginates was used, the main ones are: chelated iron $(\mathrm{Fe})-40,21 \%$, chelated manganese $(\mathrm{Mg})-19 \%$, chelated zinc (Zn)-17,35\% and boron (B)-15.24\%. The experiments were performed in the following variants:

- Variant 1 - water (control);

- Variant 2 - OMEC (0.11 g/10 l water);

- Variant 3 - OMEC (0.22 g/10 l water);

- Variant 4 - OMEC (0.33 g/10 l water);

- Variant 5 - OMEC (0.43 g/10 l water).

Repetition was 3 times. Duration of the experiment was 6 months. During this period 1 root and 1 top-dressing feeding of juniper seedlings with OMEC aqueous solution $0.11 \mathrm{~g} / 101$ water, $0.22 \mathrm{~g} / 101$ water, $0.33 \mathrm{~g} / 10 \mathrm{l}$ water, $0.43 \mathrm{~g} / 101$ water was carried out 2 times per month. No foliar and root feeding was performed on the control. Wetting the substrate in containers in all experimental variants, including the control, was carried out as needed. Determination of biomass was carried out in 3-fold repetition with division of 10 seedlings in air-dry condition into fractions: trunk, needles, roots and subsequent weighing of fractions with an accuracy of 0.1 $\mathrm{g}$ after their thermal drying.

\section{Results}

The studies showed a high efficiency of organic micronutrient complex (OMEC) effect on the biometric indicators of juniper Cossack seedlings, current seedling growth and biological mass of seedlings in air-dry state.

The results of the studies are shown in Tables 1 and 2 and in Figures 1 and 2. On the variant with the dose of OMEC $0.11 \mathrm{~g} / 10 \mathrm{l}$ of water, the growth of juniper was $7.3 \mathrm{~cm}$, which is 1.46 times higher than the growth on the control, the diameter of root neck increased 1.3 times, the length of root system increased 1.2 times (Table 1, Fig.1).

Table 1. Biometric indicators of Cossack juniper under the influence of organic micronutrient complex.

\begin{tabular}{lcccc}
\hline \multirow{2}{*}{$\begin{array}{c}\text { Experience } \\
\text { options }\end{array}$} & $\begin{array}{c}\text { Height of } \\
\text { above-ground } \\
\text { part, cm }\end{array}$ & $\begin{array}{c}\text { Root neck } \\
\text { diameter, cm }\end{array}$ & $\begin{array}{c}\text { Root system } \\
\text { length, cm }\end{array}$ & $\begin{array}{c}\text { Current } \\
\text { growth , cm }\end{array}$ \\
\hline $\begin{array}{l}\text { Variant } 1 \\
\text { (control) }\end{array}$ & 30.0 & 0.3 & 8.3 & 5.0 \\
Variant $2(0.11$ & 32.3 & 0.4 & 10 & 7.3 \\
\hline
\end{tabular}




\begin{tabular}{lcccc}
\hline $\mathrm{g} / 10 \mathrm{~L})$ & & & 11.5 & 10.2 \\
Variant $3(0.22$ & 35.2 & 0.5 & 12.3 & 10.8 \\
$\mathrm{~g} / 10 \mathrm{~L})$ & & 0.55 & 13.3 & 12.2 \\
$\begin{array}{l}\text { Variant } 4(0.33 \\
\mathrm{g} / 10 \mathrm{~L})\end{array}$ & 35.8 & 0.7 & & \\
$\begin{array}{l}\text { Variant } 5(0.43 \\
\mathrm{g} / 10 \mathrm{~L})\end{array}$ & 37.2 & & & \\
\hline
\end{tabular}

The variants with the doses of $0.33 \mathrm{~g} / 10 \mathrm{~L}$ of water and $0.43 \mathrm{~g} / 10 \mathrm{~L}$ of water showed the best efficiency in influencing the biometric parameters of Cossack juniper. The growth on these variants was 10.8 and $12.2 \mathrm{~cm}$, which is 2.16 and 2.44 times more than the growth of juniper on the control (Table 1, Fig. 1).

Root neck diameter of juniper seedlings on these variants was 0.55 and $0.7 \mathrm{~cm}$, which was 1.8 and 2.3 times more than the diameter of the root neck of juniper seedlings on the control (Table 1). The dose of OMEC $0.22 \mathrm{~g} / 101$ of water provided a 2-fold increase of juniper growth in comparison with the control (Table 1, Fig. 1), and the increase of the root neck was $66 \%$ (Table 1 ).

The increase of biometric indicators of juniper Cossack seedlings under the influence of organic micronutrient complex (OMEC) allows to reduce the terms of growing standard planting material of juniper for planting landscaping works and increase the efficiency of growing planting material of juniper Cossack.

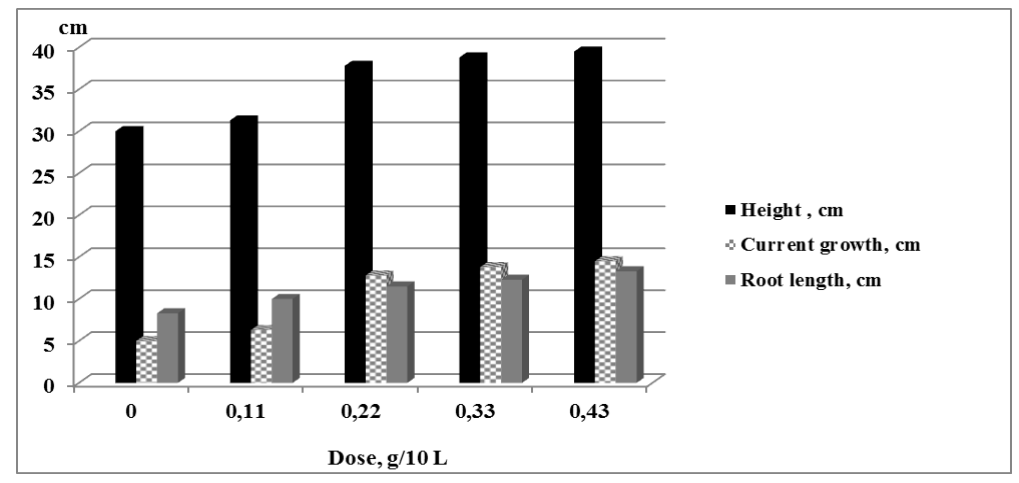

Fig. 1. Biometric indicators of juniper Cossack under the influence of organic micronutrient complex.

Dependences of seedling height and current growth of juniper seedlings on the dose of organic micronutrient complex (OMEC) are shown in Fig. 2.

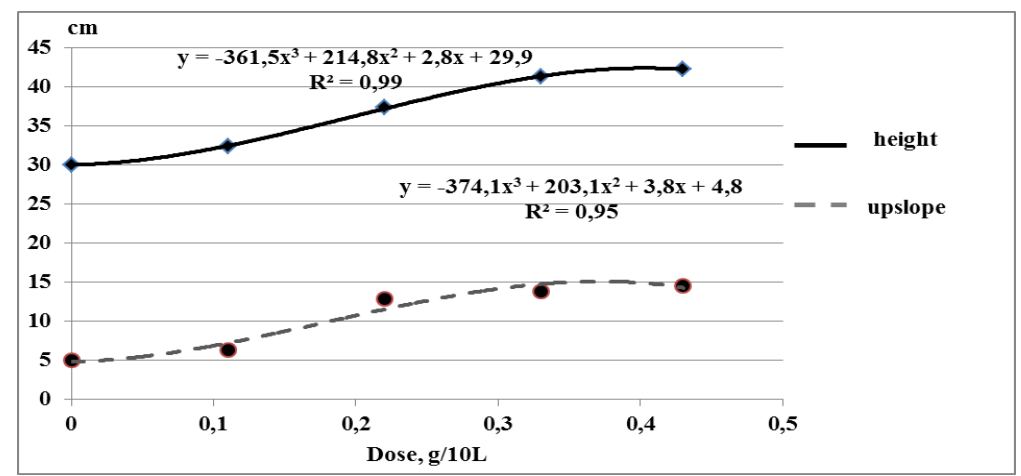

Fig. 2. Dependence of juniper seedlings growth and current growth on the dose of organic micronutrient complex. 
Dependencies are described by polynomial equations of order 3. Determination coefficients of 0.95-0.99 showed a close relationship between the height of seedlings, current growth and the dose of organic micronutrient complex (Fig. 2).

The applied doses of OMEC had a positive effect on the accumulation of biological mass of juniper seedlings. Table 2 shows values of biological mass of juniper seedlings in air-dry condition. Seedling biomass in the variant with the OMEC dose $0.11 \mathrm{~g} / 10 \mathrm{l}$ of water amounted to $67.6 \mathrm{~g}$, in the variant with $0.43 \mathrm{~g} / 10 \mathrm{l}$ of water $-88.7 \mathrm{~g}$, which is 1.2 times more and 1.6 times more than the biomass of juniper seedlings on the control (Table 2).

Table 2. Biological weight of Cossack juniper seedlings under the influence of organic micronutrient complex.

\begin{tabular}{lcccc}
\hline \multirow{1}{*}{$\begin{array}{c}\text { Experience } \\
\text { options }\end{array}$} & Stem mass, $\mathbf{g}$ & $\begin{array}{c}\text { Mass of needles, } \\
\text { g, } \mathbf{g}\end{array}$ & $\begin{array}{c}\text { Mass of the root } \\
\text { system, } \mathbf{g}\end{array}$ & Total mass, $\mathbf{g}$ \\
\cline { 2 - 5 } & 31.2 & 15.5 & 8.5 & 55.2 \\
\hline $\begin{array}{l}\text { Variant } 1 \\
\text { (control) }\end{array}$ & 33.5 & 16.9 & 17.2 & 67.6 \\
$\begin{array}{l}\text { Variant 2 }(0.11 \\
\text { g/10 L) }\end{array}$ & 34.6 & 22.6 & 17.4 & 74.6 \\
Variant 3 $(0.22$ & 35.4 & 23.3 & 23.5 & 82.2 \\
g/10 L) & & 26.7 & 24.5 & 88.7 \\
$\begin{array}{l}\text { Variant 4 }(0.33 \\
\text { g/10 L) }\end{array}$ & 37.5 & & & \\
$\begin{array}{l}\text { Variant 5 } \\
(0.43 \mathrm{~g} / 10 \mathrm{~L})\end{array}$ & & & & \\
\hline
\end{tabular}

\section{Discussion}

Distribution of seedlings biomass by fractions allows to conclude about the effective effect of OMEC on the assimilative apparatus of juniper seedlings and root system.

Thus, the share of root system in the total biomass of seedlings for the control plants was $15.4 \%$, for the variants with OMEC application these indices increase to $27.6 \%$ and to $30 \%$ respectively (dose of OMEC $-0.43 \mathrm{~g} / 101$ of water) (Table 2). Such redistribution of biomass ensures high establishment and growth of seedlings during their transplanting in the process of cultivation and planting works on landscaping objects.

\section{Conclusion}

Application of organic micronutrient complex (OMEC) in cultivation of juniper Cossack increased:

- The current growth of seedlings depending on the dose used in 1.46-2.44 times, the diameter of the root neck - in 1.3-2.3 times, the length of the root system - in 1.2-1.6 times;

- Accumulation of the biological mass of seedlings by 1.2-1.6 times compared to the control.

- The share of the root system in the total biomass of seedlings - 1.79 times, the needles - 1.1 times compared to the control.

Analysis of the growth of juniper Cossack seedlings notes a close relationship between height, current growth and the dose of organic micronutrient complex with determination coefficients of 0.95-0.98. 


\section{References}

1. J. H. Cayford, The Forestry Chronicle, 48, 5 (1972)

2. O. B. Sokolskaya, O. N. Pychin, A. A. Vergunova, E. B. Kalinichenko, IOP Conference Series: Earth and Environmental Science (2021)

3. A. L. Kalmykova, A. V. Tereshkin, G. N. Zaigralova, D. V. Eskov, M. Yu. Kornienko, Amazonia Investiga, 8 (2019)

4. T. A. Andryshko, A. V. Tereshkin, D. A. Mashtakov, Scientific Life, 12 (2018)

5. A. N. Tseplyaev, Bulletin of Altai State University, 33, 7 (2007)

6. I. A. Melnichuk, A. G. Kupriyanova, Izvestia of the St. Petersburg Forestry Academy, 179 (2007)

7. V. B. Lyubimov, M. V. Larionov, I. V. Melnikov, I. V. Moskalenko, Basic research, 2 (2015)

8. S. V. Kabanina, M. Yu. Sergadeeva, K. V. Balina, O. V. Mikhailov, V. B. Lyubimov, The container method of growing planting material and the prospects for its implementation in nurseries of Saratov region (Balashov, 2004)

9. C. E. Whitcomb, Plant Production in Containers (Stillwater, 2003)

10. B. A. Dospekhov, Methodology of field experience (with the basics of statistical processing of research results) (Moscow, 2012) 